\title{
Genotyping of Portuguese Chlamydia trachomatis urogenital isolates
}

Short report

\author{
M J Borrego, J P Gomes, J F Lefebvre, F Eb, J Orfila, M A Catry
}

Objective: To determine the prevalence of the different Chlamydia trachomatis genotypes in Portuguese patients.

Methods: Urogenital isolates $(n=240)$ derived from attenders of various clinics in the Lisbon area were differentiated into genovars by genotyping with restriction fragment length polymorphism (RFLP) analysis of the PCR amplified ompl gene.

Results: Genotype E was the most common for both men (47.9\%) and women (43.8\%). Genotypes $\mathrm{D}$ and $\mathrm{F}$ were the second most prevalent for men $(11.3 \%)$ and genotype $\mathrm{H}$ was the second most prevalent for women (19.5\%). Genotypes $F, G, D$, in women and $H, G, I$, in men, were found in a lower percentage of cases. Genotypes $\mathrm{B}, \mathrm{Ba}, \mathrm{J}, \mathrm{K}, \mathrm{L} 1$, and $\mathrm{L} 2$ were very rarely detected.

Conclusions: With one exception, the overall distribution of Chlamydia trachomatis genotypes in our study is similar to what has been observed in other western countries. The only exception is the unusual prevalence of genotype $\mathrm{H}$ among women. The clinical manifestations associated with this and other genotypes were similar.

(Genitourin Med 1997;73:561-563)

Keywords: Chlamydia trachomatis; genotypes; restriction fragment length polymorphism

\section{Introduction}

Chlamydia trachomatis is a common cause of urogenital infections and is transmitted through sexual contact. Wang et al developed immunotyping techniques defining 18 serovars of $C$ trachomatis. Serovars A-C were found to be responsible for trachoma, serovars $\mathrm{D}-\mathrm{K}$ were detected in urogenital infections and serovars $\mathrm{L}_{1}-\mathrm{L}_{3}$ were considered to be capable of inducing lymphogranuloma venereum. ${ }^{1}$ We report here the results of a genotyping study on Portuguese $C$ trachomatis isolates using two polymerase chain reaction (PCR) techniques to amplify the ompl gene that encodes the major outer membrane protein (MOMP) and a restriction fragment length polymorphism (RFLP) method to examine positive PCR products. ${ }^{2}{ }^{3}$ The aim of this work was to estimate the prevalence of the different $C$ trachomatis genotypes and to look for a relation between pathology and genotype.

\section{Materials and methods}

\section{CHLAMYDIA TRACHOMATIS ISOLATES}

During the period 1991-6, individuals from clinics for sexually transmitted diseases (STD), family planning, gynaecology, and dermatology or urology located in the Lisbon area, were screened for $C$ trachomatis urogenital infection. All women had samples taken from the cervix. Samples from men were urethral swabs or urine. To diagnose urogenital chlamydial infection, McCoy cell culture and Amplicor $C$ trachomatis test were performed as previously described.

\section{OMP1-RFLP GENOTYPING TECHNIOUE}

A volume of $200 \mu$ l of positive $C$ trachomatis culture or $200 \mu \mathrm{l}$ of Amplicor positive "prepared patient specimen" were added to $800 \mu \mathrm{l}$ lysing buffer (KCl-TRIS-HCl- $\mathrm{MgCl}_{2}$-Nonidet/ P40-Tween/20-ProteinaseK). The $C$ trachomatis ompl gene present in the lysates was amplified by a single PCR or a nested PCR, as previously described. ${ }^{23}$

PCR products presenting a DNA fragment of approximately $1.1 \mathrm{~kb}$ (single PCR) or $1 \mathrm{~kb}$ (nested PCR) in agarose gel were considered for RFLP analysis. For RFLP genotyping, the positive $o m p 1$ PCR products were principally digested with AluI restriction enzyme (Boehringer) and analysed, by electrophoresis on a $7 \%$ polyacrylamide gel, to differentiate genotypes $\mathrm{B}, \mathrm{Ba}, \mathrm{D}, \mathrm{E}, \mathrm{F}, \mathrm{G}$, and $\mathrm{K}$. The $\mathrm{C}$ complex genotypes were further differentiated by digestion of the $o m p 1$ PCR product with EcoRI (Boehringer) to distinguish $\mathrm{H}$, I, Ia, from $\mathrm{L}_{3}$ and DdeI (Boehringer) to distinguish $\mathrm{H}$ from I and Ia. HinfI (Boehringer) was used to distinguish strains $\mathrm{J}$ and $\mathrm{C}$.

\section{OMP1 RFLP GENOTYPING PRODUCTS}

The following reference strains of $C$ trachomatis, kindly supplied by Professors J Treharne (London) and J Orfila (Amiens)-A/SA-1, B/TW-5, C/TW-1, D/IcCal-8, E/Bour, F/MRC-301, G/IOL-238, H/UW-4, I/UW-12, J/UW-36, K/UW-31, $\mathrm{L}_{1} / 440 \mathrm{~L}, \mathrm{~L}_{2} / \mathrm{LB} 1$ and $\mathrm{L}_{3} / 404 \mathrm{~L}$ - were used for establisment of RFLP patterns. Positive ompl PCR products $(\mathrm{n}=$ 240) were subjected to the ompl-RFLP genotyping method described above. The patterns obtained were compared with those of reference strains submitted to the same PCR and RFLP procedures.

In all, 140 of these positive specimens were obtained from patients attending STD clinics and 100 from patients attending other clinics; 169 of the positive specimens were collected from women and 71 from men. The men were 
aged 17 to 56 years; $23(32 \cdot 4 \%)$ were younger than 25 years, $36(50 \cdot 7 \%)$ were aged 26 to 35 , and $12(16.9 \%)$ were older than 36 years. The women were aged 15 to 61 years; $85(50 \cdot 3 \%)$ were younger than 25 years, $57(33.7 \%)$ were aged 26 to 35 years, and $27(16 \%)$ were older than 36 years. All patients participating on the present study were heterosexual.

\section{Results}

$C$ trachomatis genotypes E: 34 men (47.9\%), 74 women $(43.8 \%) ; \mathrm{H}$ : six men $(8.5 \%), 33$ women $(19.5 \%) ; \mathrm{F}$ : eight men $(11.3 \%), 21$ women $(12.4 \%)$; D: eight men $(11.3 \%)$, eight women $(4 \cdot 7 \%)$; and $\mathrm{G}$ : four men $(5 \cdot 6 \%), 12$ women $(7 \cdot 1 \%)$ were the genotypes most commonly found. The overall distribution of genotypes is shown in the figure. A strain isolated from an endocervical sample was identified as $\mathrm{Ba}$, by comparing its profile on acrylamide gel with that published by Sayada et $a l^{2}$ for this genotype. Two mixed infections were detected in men ( $G+$ unidentified and $E+C$ complex), and six in women $(\mathrm{G}+\mathrm{H}, \mathrm{E}+\mathrm{C}$ complex, $\mathrm{G}+$ $\mathrm{E}, \mathrm{H}+$ unidentified, $\mathrm{L}_{2}+\mathrm{E}$ and $\left.\mathrm{F}+\mathrm{H}\right)$. In nine cases the amount of PCR product was insufficient for a good RFLP analysis. This situation led to the unidentified strains of mixed infections and enabled further typing of three C complex strains (two coexisting with other strains in mixed infections). Five strains submitted to the $o m p 1$ nested PCR technique presented an acrylamide gel profile similar to $\mathrm{D}$, but including an extra band of about 70 base pairs (D-like). We considered the typing of all these strains as incomplete. For further analysis

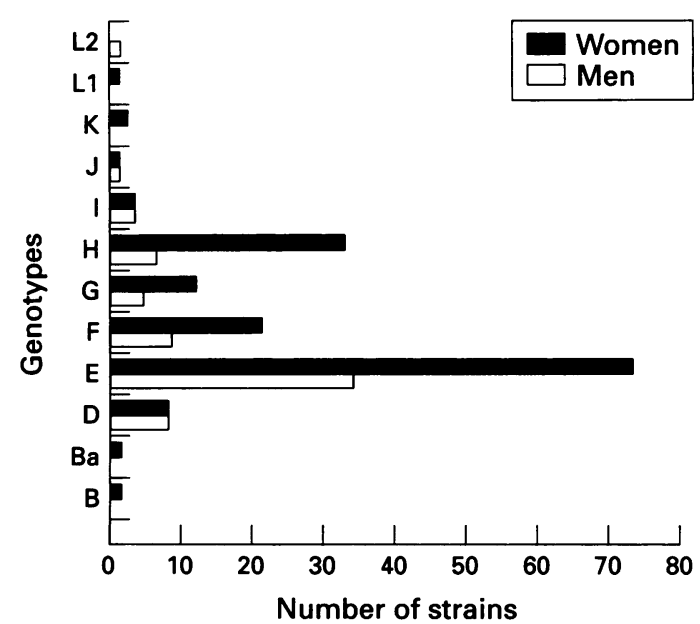

Distribution of Chlamydia trachomatis genotypes isolated in urogenital specimens of patients attending to clinics of the Lisbon area.

Association between Chlamydia trachomatis genotype and clinical findings (Number of cases per genotype)

\begin{tabular}{|c|c|c|c|c|c|c|c|c|c|c|c|c|}
\hline & $B$ & $B a$ & $D$ & $E$ & $F$ & $G$ & $H$ & $I$ & $\boldsymbol{f}$ & $K$ & $L_{t}$ & $L_{2}$ \\
\hline $\begin{array}{l}\text { Men: } \\
\text { Urethritis } \\
\text { Women: }\end{array}$ & & & 8 & 34 & 8 & 4 & 6 & 3 & 1 & & & 1 \\
\hline $\begin{array}{l}\text { Cervicitis } \\
\text { Abdominal pain, PID } \\
\text { Vaginal discharge } \\
\text { Asymptomatic }\end{array}$ & 1 & 1 & $\begin{array}{l}5 \\
2\end{array}$ & $\begin{array}{r}32 \\
4 \\
9 \\
19\end{array}$ & $\begin{array}{r}11 \\
4 \\
2\end{array}$ & $\begin{array}{l}4 \\
1\end{array}$ & $\begin{array}{r}18 \\
1 \\
2 \\
8\end{array}$ & $\begin{array}{l}2 \\
1\end{array}$ & 1 & 1 & 1 & \\
\hline
\end{tabular}

of clinical signs associated with $C$ trachomatis genotypes, mixed infections and incomplete typing cases have been excluded. The table presents the clinical findings in relation to $C$ trachomatis genotypes, in absolute numbers. All men were reported as urethritis patients, and no asymptomatic man was included in our study. No pathology data were available for $23 \mathrm{C} \mathrm{tra-}$ chomatis patients and so they are not included in the table. In our study group $\mathrm{E}$ and $\mathrm{H}$ represented respectively $42.9 \%$ and $11.9 \%$ of the genotypes detected in women aged up to 25 years. In women older than 25 years strains $\mathrm{E}$ and $\mathrm{H}$ constitute respectively $44 \cdot 7 \%$ and $27 \cdot 1 \%$ of the isolates. During the study period seven women presented with more than one episode of $C$ trachomatis infection. All these women, except one, suffered from cervicitis at the time of the first clinical observation. A woman infected by a strain $\mathrm{E}$ was asymptomatic at the first visit. However, 1 year later, when another strain $\mathrm{E}$ was detected, also she presented with cervicitis. Five of these seven women had two episodes of infection by the same strain. The second episode occurred within 4 months (strain F), 3 weeks $/ 3$ months/ 1 year (strain E), and 1 week (strain $\mathrm{H}$ ). The second episode may be due to reinfection (by the same or another partner) or as a consequence of the first untreated episode of infection. The omp1RFLP typing technique was not an epidemiological marker sufficiently discriminative to elucidate these five double episodes of infection. One of these seven patients was first infected by strain $E$ and 1 week later by strain H. A woman seropositive for the human immunodeficiency virus (HIV), presented with five infectious episodes, by five different genotypes (1992-6). In this patient, strains $\mathrm{E}, \mathrm{Ba}, \mathrm{F}$, $\mathrm{L}_{2}+\mathrm{E}$, and $\mathrm{H}$ were successively identified.

\section{Discussion}

In other epidemiological studies there was no difference in proportions of genotypes found between men and women. ${ }^{5}$ In our study these proportions were slightly different. The genotypes observed by decreasing prevalence were: $E, H, F, G$, and $D$ in women and $E, D / F, H$, and $G$ in men. An unusual finding in our study was genotype $\mathrm{H}$ being the second most detected in females, $19.5 \%$. In other studies, ${ }^{6-8}$ genotype $\mathrm{F}$ was the second most common. A major similarity with published studies is the predominance of genotype E. ${ }^{15-8}$ In general, strain $\mathrm{E}$ seems to be the most prevalent $C$ trachomatis type independent of the population studied or the typing technique. A study that intended to relate $C$ trachomatis serovar and race admits that some serovars could circulate more often in relatively closed populations. ${ }^{7}$ In our study, the $\mathrm{H}$ genotype is found more often in patients from one STD clinic, located in a area of Lisbon where there is a high rate of commercial sex (15/41 genotypes $\mathrm{H})$. A study of serovar distribution performed by Lan et al showed that it was not age dependent. ${ }^{8}$ In our study, a relation between prevalence of serovars and age was, in general, not observed. However, serovar $\mathrm{H}$ was significantly associ- 
ated $(\mathrm{p}<0.01)$ with women aged over 25 years. Barnes et al proposed a relation between mixed infections and exposure to various $C$ trachomatis strains caused by multiple partners. ${ }^{9}$ Indeed, in our study, five of eight patients infected with more than one strain were sex workers attending STD clinics. No particular pathology could be related to one of the $C$ trachomatis genotypes. However, we cannot neglect that some infections, such as pelvic inflammatory disease, have little representation $(n=6)$, or that some genotypes are present in the study group as a single isolate. Van de Laar et al obtained similar results for women but, for men, they found serovars $F$ and $G$ as causing significantly fewer symptoms of urethral discharge. ${ }^{6}$ In the present study we cannot reach such conclusions because no data on acute inflammatory response were available. Variations in Portuguese $D$ strains have already been reported by others. ${ }^{10}$ In our study we detected 4 D-like strains; however, no particular pathology was associated with them. Further complete studies are needed to elucidate the relation between $C$ trachomatis and pathology.

We thank Drs I Cardoso, I Santo, J Azevedo, and P Lamarão for providing most of the samples and clinical data and the
Portuguese Junta Nacional de Investigação Científica e Tecnológica for financial support.

1 Wang SP, Kuo CC, Barnes RC, Stephens RS, Grayston JT. Immunotyping of Chlamydia trachomatis with monoclonal antibodies. $\mathcal{F}$ Infect Dis 1985;152:791-800.

2 Sayada C, Denamur E, Orfila J, Catalan F, Elion J. Rapid genotyping of the Chlamydia trachomatis major outer membrane protein by the polymerase chain reaction. FEMS Microbiol Lett 1991;83:73-8.

3 Lan J, Ossewaarde JM, Walboomers JMM, Meijer CJLM, van den Brule AJC. Improved sensitivity for direct genotyping of Chlamydia trachomatis serovars by using nested PCR. F Clin Microbiol 1994;32:528-30.

4 Catry MA, Borrego MJ, Cardoso J, Azevedo J, Santo I. Comparison of the Amplicor Chlamydia trachomatis test and cell culture for the detection of urogenital chlamydial infections. Genitourin Med 1995;71:247-50.

5 Frost EH, Deslandes S, Bourgaux-Ramoisy D. Chlamydia trachomatis serovars in 435 urogenital specimens typed by restriction endonuclease analysis of amplified DNA. $\mathcal{F}$ Infect Dis 1993;168:497-501.

6 van de Laar MJW, Lan J, van Duynhoven YTHP, Fennema JSA, Ossewaade JM, van den Brule AJC, et al. Differences in clinical manifestations of genital chlamydial infections related to serovars. Genitourin Med 1996; 72:261-5.

7 Workowski KA, Suchland RJ, Pettinger MB, Stamm WE. Association of genital infection with specific Chlamydia trachomatis serovars and race. $\mathcal{F}$ Infect Dis 1992;166: trachomatis

8 Lan J, Melgers I, Meijer CJLM, Walboomers JMM, Roosendaal R, Burger C, et al. Prevalence and serovar distribution of asymptomatic cervical Chlamydia trachomatis infections as determined by highly sensitive PCR. F Clin Microbiol 1995;33:3194-7.

9 Barnes RC, Suchland RJ, Wang SP, Kuo CC, Stamm WE. Detection of multiple serovars of Chlamydia trachomatis in genital infections. $\mathcal{F}$ Infect Dis 1985;152:985-9.

10 Sayada C, Vretou E, Orfila J, Elion J, Denamur E. Heterogeneity within the first constant segment of the major outer membrane protein in Chlamydia trachomatis serovar D/Da distinguishes 2 lineages. CR Acad Sci Paris 1995;318:943-9. 